\title{
MONEY, INCOME, AND CAUSALITY: AN EXAMINATION FOR THE TURKISH ECONOMY
}

\author{
Şeref BOZOKLU \\ ${ }^{a}$ Dr., Istanbul University, Department of Economics, 34452, Fatih, Istanbul, Turkey, sbozoklu@istanbul.edu.tr
}

\section{ARTICLE INFO}

Article data:

- Received: 5 January 2012

- Accepted: 28 June 2012

JEL classification: C32, C63, E51

Keywords:

- Money-income Causality

- Monetary Endogeneity

- MWALD test

- Leveraged Bootstrap Simulation

- Toda-Yamamoto

\begin{abstract}
This paper examines the direction of causality between money and income for the Turkish economy using quarterly data over the period of 1987 to 2011. A vector autoregression model consisting of the real gross domestic product, the broad money supply, the three months deposit rate as short-term interest rate, and the consumer price index is constructed to implement causality tests. Also, a leveraged bootstrapped simulation technique is used when conducting causality tests in order to make the results more robust. The empirical results suggest a bidirectional causation between the two variables and that monetary aggregates may provide relevant information in the implementation of monetary policy.
\end{abstract}

Reference to this paper should be made as follows: Bozoklu, Ş. 2013. Money, Income, and Causality: An Examination for the Turkish Economy, Ekonomska istraživanja - Economic Research 26(1):171-182. 


\section{INTRODUCTION}

The relationship between money and income has important implications for both theoretical and empirical models in monetary economics. Whether or not monetary (income) changes help to predict changes in income (money) has been an ongoing debate among researchers and policy makers, as understanding the direction of the causality may improve the efficiency of policy rule stipulated by the monetary authority. Theoretical explanations concerning direction of causality can be divided into two categories, the first of which asserts that causality runs from money to income, and the second of which claims that causality follows in the opposite direction.

Among the first category, Monetarists believe that changes in monetary growth are responsible for the divergence of income from its trend level -in other words, monetary changes lead to changes in income. Monetarists, therefore, suggest that a rule characterized by a constant growth of money supply must be used to stabilize income fluctuations (Friedman, 1959). The modern view of (short-run) monetary non-neutrality as expressed by the new-Classical economics, which emphasizes imperfect information between economic agents, is the other explanation for direction of causality from monetary changes to income fluctuations (Lucas, 1972; Barro, 1976). The new-Classics claims that anticipated monetary policy has no lasting effects on real income when economic participants form expectations rationally, and only unexpected movements in money stock are the driving forces behind business cycles (Lucas, 1975; Sargent and Wallace, 1975). In addition, the sticky-wage or sticky-price models of the newKeynesians can be attributed to this category (Gray, 1976; Fisher 1977; Taylor, 1980). The newKeynesians claim that, whether anticipated or not, the demand management policy proxies, such as discretionary government expenditures, tax cuts, and monetary policies, determine real income. Despite varying theoretical propositions, the new-Keynesians hold a general opinion regarding the non-neutrality of stabilization policy (Gordon, 1982; Demary, 1984). Consequently, all views in the first category suggest that the direction of causality runs from money to income.

The traditional Keynesians, by contrast, argue that money does not play any significant role in changing income. In fact, changes in income cause changes in money stocks through demand for money, implying a unidirectional causality from income to money. Keynesians, therefore, doubt that controlling money supply will reduce fluctuations in income. Furthermore, the post-Keynesians assert that money supply is determined endogenously via the asset-liability management decisions of commercial banks, the portfolio decisions of the non-bank public, and the demand for bank loans. Thus, according to the traditional and post-Keynesian approaches, the amount of money supplied is dependent on the interaction of the private sector's demand to hold money and also the ability and willingness of banks to extend credit (Palley, 1994). As a result, the Keynesian theory predicts that causality runs from income to money, and not the exogenous notion that money creates income. The Real Business Cycle (RBC) theory argues that observed historical correlation between money and income is because the money supply endogenously responds to rather than leads to fluctuations in income (Kydland and Prescott, 1982). The banking sector responds to increased demand for transactions by creating more inside money, so that money supply becomes both endogenous and a function of income, which is determined exogenously by technological shocks and changes in productivity, energy prices, government spending, and taxes (Long and Plosser, 1983). The new Neoclassical Synthesis (NNS) combines the new-Classical and new-Keynesian elements within a dynamic stochastic general equilibrium framework popularized by the RBC approach. The NNS approach suggests money to be endogenous, treating money stock as residual based on the demand for money, and proposes that supply shocks are random, as posited by the RBC theory. In addition, actual and expected rates of inflation are independent of such supply shocks. The inflation can be controlled through interest rate policy, but cannot be controlled through money stock (Goodfriend and King, 1997). 
Consequently, all views in the second category suggest that the direction of causality runs from income to money.

The aim of this study is to examine the causal relationship between money and income for the Turkish economy. The Granger causality approach of Toda and Yamamoto (1995) and its extension, developed by Hacker and Hatemi-J (2006), which uses the leveraged bootstrap simulation approach that performs well when the sample size is relatively small, is employed for the empirical section. The remainder of this article is organized as follows: Section 2 reviews previous empirical studies on the money-income relationship, Section 3 describes the data set and econometric methodology and also presents estimation results, while conclusions and policy implications are presented in Section 4.

\section{SELECTIVE LITERATURE REVIEW}

The link between money and income has long been the subject of investigation, much of which is supportive of a systematic link to the United States prior to the 1980s, as indicated by Friedman and Schwartz (1963), Andersen and Jordan (1968), and later by Sims (1972). The pioneering work of Friedman and Schwartz (1963) finds that money prominently affects income, and Andersen and Jordan (1968), using the St. Louis equation, suggest that monetary policy, measured as the rate of growth of nominal money, explains fluctuations in income. As it is difficult to distinguish cause from effect using historical correlation patterns, Sims (1972) offers a testing procedure that depends on the basic regression, including income as the dependent variable, and lagged income with money as explanatory variables. Using postwar the United States data, Sims (1972) asserts that there is strong evidence that money creates income because money lags improve forecasts of income, and forecasts of money cannot be improved using income lags. However, considering the possible effects of variables other than money and income, Sims (1980) proposes a vector autoregression (VAR) framework and reveals that the direction of causality vanishes when a short-term interest rate is included as a control variable. If interest rate is dropped from the data, however, the explanatory power of money rises significantly (a phenomenon often referred to as Sims' puzzle). After Sims (1980), most empirical studies involved VAR models, to analyze the causal relationship between money and income. This causation depends, among other things, on the choice of variables included in the model, the method used to transform the data, the specification of the trend term, and the sample period under consideration.

The sensitivity of causality tests to the sample period, whether or not the variables are modeled as log-level, growth rate, trend stationary, or difference stationary, is documented by many studies. Eichenbaum and Singleton (1986), for example, emphasize that a causal role for money in a detrended level specification is much weaker in a sample that excludes the 1980s than if the 1980s are included. If attention is restricted to a sample period that ends before the 1980 s, causality tests support the argument that money causes income. They also show that there are sharp reductions in the importance of money when the tests are performed using log differences of the variables rather than log levels with a time trend. Christiano and Ljungquist (1988) argue in favor of using log-level variables, because they find that the power of the tests on growth variables is very low. Using bootstrap simulations, they find significant Granger causality from money to income within a bivariate VAR model. Stock and Watson (1989) claim that money growth is stationary around a linear time trend and, when detrended money growth is used in testing money-income causality, the results are in fact robust to the empirical specification, to the sample period and to whether or not interest rates are included in the set of explanatory variables. Accordingly, removing deterministic trends from the growth rate of the money supply enhances the explanatory power of money in output autoregressions, while the use of log-differenced data results in money playing only a small role in explaining output 
fluctuations. To solve this trend puzzle, Serletis and King (1994), following Stock and Watson (1989), investigate whether money growth rates can be characterized by deterministic time trends, and whether or not removing these trends significantly affects statistical inference for both the United States and Canada. They find evidence that, for both countries, the broader measures of money appear to have strong negative deterministic trends, but that removing these trends does not appear to sharpen the statistical inference linking money growth to output growth. Friedman and Kuttner (1993) reexamine the study of Stock and Watson (1989) and assert that money-income causality results are not robust to two changes: first, when the sample is extended to 1990, money is statistically insignificant using Stock and Watson's specification, and, second, if the treasury bill rate is replaced with the commercial paper rate, then money offers little explanatory power, even when Stock and Watson's sample period (1960-1985) is used. Hatemi-J and Irandoust (2006) study the relationship between money and income using the leveraged bootstrapped simulation technique to determine the direction of the causality for Denmark, Japan, Sweden, and the United States. Their results indicate that money might be a major factor for the sources of income fluctuations and that Granger causality is unidirectional running from money to output in all the sample countries except for Sweden for which the direction of causality is bidirectional.

\section{DATA AND ECONOMETRIC TECHNIQUES}

In this section, we briefly describe the time series characteristics of the data and the methods employed to test the direction of causality in the money-income relationship. The data obtained from International Financial Statistics database ${ }^{a}$ include the quarterly observation of the real gross domestic product (RGDP), the broad money supply (M2), the three months deposit rate as short-term interest rate (TMDR), and the consumer price index (CPI) for the Turkish economy. All data are seasonally adjusted and expressed in natural logarithmic form, except for the interest rate. The sample period covers $1998 \mathrm{q} 1$ to $2011 \mathrm{q} 2$. To begin, we first examine the stationarity properties of the variables via unit root tests of $\mathrm{Ng}$ and Perron (2001), who propose several modifications to existing unit root tests in order to improve their size and power. They present the following tests: $M Z_{\alpha}$ and $M Z_{t}$ which are the modified versions of $Z_{\alpha}$ and $Z_{t}$ tests of Phillips (1987) and Phillips and Perron (1988), the MSB which is related to Bhargava (1986) $R_{1}$ test; and finally, the MPT test which is a modified version of Point Optimal Test of Elliot et al. (1996). Furthermore, Ng and Perron (2001) suggest a modifed information criterion that controls for sample size and the generalized least squares method for detrending the data in order to improve the power of the tests.

The optimal lag order of VAR model $(p)$ is determined using the information criterion developed by Hatemi-J (2003 and 2008), which performs well if the variables are integrated. The Hatemi-J Information Criterion (HJC) that minimizes the following equation is calculated as follows:

$$
H J C=\ln \left(\operatorname{det} \widehat{\Omega}_{s}\right)+j \bigsqcup \frac{\square n^{2} \ln T+2 n^{2} \ln (\ln T)}{2 T} \downarrow, j=0, \ldots, p
$$

where $\operatorname{det} \widehat{\Omega}_{s}$ is the determinant of the estimated variance-covariance matrix of the error terms in the VAR model for the lag order $j, n$ is the number of variables and $T$ is the number of

\footnotetext{
${ }^{\text {a } h t t p: / / e l i b r a r y-d a t a . i m f . o r g / ~}$ 
observations used to estimate the VAR model. The notation In indicates natural logarithms. The optimal lag order is the one that minimizes the equation (1).

A variable Granger causes another variable, if including it in the information set will improve the forecast of the second variable. The VAR models are generally utilized to test for Granger causality, which is sensitive to the values of nuisance parameters in finite samples. Therefore, it is possible that misleading inferences could be made about the issue of causality. For this reason, we use the Toda and Yamamoto (1995) (TY) procedure, which has the advantage of implementing, regardless of whether the processes are integrated or even cointegrated. TY suggests a modification of the Wald test that is robust to the presence of unit roots in the underlying data set. The basic idea of this approach is to artificially augment the correct $p$ with $d$ extra lags, where $d$ is the maximum likely order of integration of the series in the system. The asymptotic chi-squared $\left(\chi^{2}\right)$ distributed Modified Wald (MWALD) test is applied to the first $p$-VAR coefficient matrix, while the coefficient matrices of the last $d$ lagged vectors in the model are ignored. Therefore, the TY approach enables the proposed MWALD statistic to test restrictions on these $p$ coefficient matrices, using the standard asymptotic theory.

To implement the TY causality test, we estimate the following augmented-VAR framework with the lag length, $(p+d)$ :

$$
y_{t}=\alpha+A_{t-1} y_{t-1}+\ldots+A_{p} y_{t-p}+\ldots+A_{p+d} y_{t-p-d}+\varepsilon_{t}
$$

where $y_{t}, \alpha$ and $\varepsilon_{t} m$-dimension vectors and $A_{p}$ is a $n \times n$ matrix of parameters for lag $p$. The residuals $\varepsilon_{t}$ are assumed to be normally distributed and white noise. We partition $y_{t}$ in two sub-vectors, $y_{t}^{1}$ and $y_{t}^{2}$ :

$$
\begin{gathered}
y_{t}=\left[\begin{array}{l}
y_{t}^{1} \\
y_{t}^{2}
\end{array}\right]=\left[\begin{array}{l}
\alpha_{1} \\
\alpha_{2}
\end{array}\right]+\left[\begin{array}{ll}
A_{11,1} & A_{12,1} \\
A_{21,1} & A_{22,1}
\end{array}\right] \times\left[\begin{array}{l}
y_{t-1}^{1} \\
y_{t-1}^{2}
\end{array}\right]+\ldots+\left[\begin{array}{ll}
A_{11, p} & A_{12, p} \\
A_{2 l, p} & A_{22, p}
\end{array}\right] \times\left[\begin{array}{c}
y_{t-p}^{1} \\
y_{t-p}^{2}
\end{array}\right] \\
+\left[\begin{array}{ll}
A_{11, p+d} & A_{12, p+d} \\
A_{21, p+d} & A_{22, p+d}
\end{array}\right] \times\left[\begin{array}{l}
y_{t-p-d}^{1} \\
y_{t-p-d}^{2}
\end{array}\right]+\left[\begin{array}{l}
\xi_{1 t} \\
\xi_{2 t}
\end{array}\right]
\end{gathered}
$$

where $p$ is the optimal lag order in the VAR system. From Equation (3), it follows that $y_{t}^{2}$ does not Granger-cause $y_{t}^{1}$ if $A_{12, p}=0 \forall_{p}$ holds and $y_{t}^{1}$ does not Granger-cause $y_{t}^{2}$ if $A_{21, p} \neq 0 \forall{ }_{p}$ holds. The residuals $\xi_{1 t}$ and $\xi_{2 t}$ are assumed to be spherically distributed and white noise.

It should be pointed out that the parameters for the extra $\operatorname{lag}(\mathrm{s}), d$, are unrestricted under the null hypothesis and that these unrestricted parameters ensure that the asymptotical distribution theory can be applied when the test for causality between the integrated variables is conducted. We make use of the following notations in order to describe the TY test statistic in a compact way: 


$$
\begin{aligned}
& Y:=\left(y_{1}, \ldots, y_{T}\right) \quad(n \times T) \text { matrix, } \\
& D:=\left(\alpha, A_{1}, \ldots, A_{p+d}\right) \quad(n \times(1+n(p \times d))) \text { matrix } \\
& W_{t}:=\left[\begin{array}{c}
1 \\
y_{t} \\
y_{t-1} \\
\vdots \\
y_{t-p-d+1}
\end{array}\right] \quad((1+n(p+d)) \times 1) \text { matrix, } \\
& W_{t}:=\left(W_{0}, \ldots, W_{T-1}\right) \quad((1+n(p+d)) \times T) \text { matrix, } \\
& \text { and } \quad(n \times T) \text { matrix. } \\
& \delta:=\left(\varepsilon_{1}, \ldots ., \varepsilon_{T}\right) \quad\left(\begin{array}{c} 
\\
\delta
\end{array}\right]
\end{aligned}
$$

These definitions allow us to write the augmented VAR $(p+d)$ model in a simple form as follows:

$$
Y=D W+\delta
$$

The $(n \times T)$ matrix of the estimated residuals from the unrestricted and restricted regression can be denoted by $\hat{\phi}_{U}$ and $\hat{\phi}_{R}$. The matrix of the cross products of these residuals can now be defined as $S_{U}=\hat{\phi}_{U}^{\prime} \hat{\phi}_{U}$ and $S_{R}=\hat{\phi}_{R}^{\prime} \hat{\phi}_{R}$, respectively. The MWALD test statistics proposed by TY can be written as the following:

$$
M W A L D=(T-p) \times \frac{\left(S_{R}-S_{U}\right)}{S_{U}}
$$

In a nutshell, the MWALD testing procedure should occur as follows: 1 ) determine the maximum order of integration $\left(d_{\max }\right)$ of the data and the lag length $(p)$ of the VAR model; 2$)$ estimate the $(p+d)$ th-order VAR model and finally; 3 ) test restrictions on the first $p$ coefficient matrices, ignoring the last $d$-lagged vectors in the model.

Hacker and Hatemi-J (2006) show that this modified test performs well only if the data is normally distributed and go on to develop a leveraged bootstrap test that is not sensitive to non-normality and time-varying volatility. In addition, the leveraged bootstrap test approach performs well when the sample size is relatively small. In this study, the residuals-based bootstrapping approach will be adopted to compute the critical values for the MWALD test with the empirical distribution. To carry out the bootstrap simulations, we estimate the regression, using Equation (4), with the restriction for the null hypothesis of no Granger causality imposed. 
We rescale the estimated raw residuals $(\widehat{\delta})$ with the leverages approach to ensure constant variance and compute the adjusted residuals $(\widehat{\delta}-\bar{\delta})$ to ensure that the mean of the adjusted residuals is zero. For each bootstrap simulation, we generate the simulated data, $Y_{t}^{*}$, based on the coefficient estimates from this regression, $\bar{D},\left(\hat{\alpha}_{1}, \hat{A}_{1}, \ldots, \hat{A}_{p}\right)$; the original data, $Z$, $\left(y_{t-1}, \ldots, y_{t-p}\right)$; and the bootstrapped residuals $\hat{\delta}^{*}$ :

$$
Y_{t}^{*}=\hat{D} Z+\widehat{\delta}_{t}^{*}
$$

where $\widehat{D}$ is estimated from the following equation:

$$
\widehat{D}=Y Z^{\prime}\left(Z Z^{\prime}\right)^{-1}
$$

It should be pointed out that the bootstrap residuals are based on $T$ random draws with replacement from the regression's modified residuals, each with equal probability of $1 / T$.

We perform bootstrap simulation to calculate the MWALD test statistic and derive the bootstrap critical values from the MWALD statistics distribution. The next step is to calculate the MWALD statistic using the original data. If the actual MWALD test statistic is greater than bootstrap critical values, then the null hypothesis of non-Granger causality will be rejected; otherwise, we failed to reject the null hypothesis.

\section{ESTIMATION RESULTS}

The first step in our empirical analysis is to test for unit roots using the Ng and Perron (2001) test. The results of these unit root test are presented in Table 1, which shows that the variables contain a unit root, except for the consumer price index.

\begin{tabular}{|c|c|c|c|c|c|}
\hline $\begin{array}{l}\mathrm{H}_{0}: \mathrm{I}(1) \\
\mathrm{H}_{1}: \mathrm{I}(0)\end{array}$ & vs & $M Z_{\alpha}$ & $M Z_{t}$ & $M S B$ & $M P T$ \\
\hline $\begin{array}{l}\text { CPI (6) } \\
\text { M2 (5) } \\
\operatorname{RGDP~(1)~} \\
\operatorname{TMDR}(3)\end{array}$ & & $\begin{array}{c}-27.626^{*} \\
-11.187 \\
-8.781 \\
-9.368\end{array}$ & $\begin{array}{l}-3.651^{*} \\
-2.282 \\
-2.072 \\
-2.113\end{array}$ & $\begin{array}{l}0.132^{*} \\
0.204 \\
0.236 \\
0.225\end{array}$ & $\begin{array}{c}3.681^{*} \\
8.562 \\
10.460 \\
9.935\end{array}$ \\
\hline $\begin{array}{l}\mathrm{H}_{0}: \mathrm{I}(2) \\
\mathrm{H}_{1}: \mathrm{I}(1)\end{array}$ & vs & $M Z_{\alpha}$ & $M Z_{t}$ & $M S B$ & $M P T$ \\
\hline $\begin{array}{l}\text { M2 (0) } \\
\operatorname{RGDP}(0) \\
\operatorname{TMDR}(1)\end{array}$ & & $\begin{array}{l}-19.348^{* *} \\
-24.683^{*} \\
-35.197^{*}\end{array}$ & $\begin{array}{l}-3.064^{* *} \\
-3.486^{*} \\
-4.187^{*}\end{array}$ & $\begin{array}{l}0.158^{* *} \\
0.141^{*} \\
0.118^{*}\end{array}$ & $\begin{array}{l}4.988^{* *} \\
3.851^{*} \\
0.718^{*}\end{array}$ \\
\hline
\end{tabular}

Table 1. THE RESULTS OF NG-PERRON UNIT ROOT TESTS

Notes: The lag lengths in the Ng-Perron tests were selected using spectral GLS-detrended based on Schwarz Bayesian Information Criterion. The deterministic trend components were selected by a procedure suggested by Hacker and Hatemi-J (2010). (.) indicates the number of lags. The critical values are -23.8, -3.42, 0.143, 4.03 at the 1\% level and $-17.3,-2.91,0.168,5.48$ at the 5\% level for MZa, MZt, MSB and MPT tests respectively. ${ }^{*}$ and ${ }^{* *}$ denotes the stationarity of the related variable at the $1 \%$ and $5 \%$ significance levels.

Source: Research results 
We select the optimal lag of the VAR model ( $p$ ) one, based on minimizing equation ( 1 ), and the augmentation lag $(d)$ one since each variable contains one unit root. The test for multivariate normality is carried out using the Doornik and Hansen (2008) test. The estimated $p$-value for this test is 0.002 , which means the null hypothesis of normality can be strongly rejected. Also, a multivariate test for multivariate autoregressive conditional heteroskedasticity (ARCH) effects, developed by Hacker and Hatemi-J (2005), indicates that estimated $p$-value for this test is less than 0.004 , which implies that the null hypothesis of no multivariate $\mathrm{ARCH}$ effects can be rejected at any conventional significance level. Therefore, it is essential to make use of the bootstrap method in order to draw accurate inferences from the causality tests. The outcome of the bootstrapped causality test with leverage adjustments is presented in Table 2.

Table 2. THE RESULTS OF MWALD TESTS

\begin{tabular}{ccccc}
\hline \hline & & $1 \%$ bootstrap & $5 \%$ bootstrap & $10 \%$ bootstrap \\
Null Hypothesis & MWALD statistic & critical value & critical value & 7.812 \\
RGDP $\rightarrow$ M2 & $18.384^{*}$ & 12.435 & 7.473 \\
M2 $\rightarrow$ RGDP & $8.411^{* * *}$ & 12.673 & 8.573 & 6.978 \\
\hline \hline
\end{tabular}

Notes: The null hypothesis $(A \rightarrow B)$ implies that A does not Granger cause B. ${ }^{*}$ and ${ }^{* * *}$ denotes the rejection of the null hypothesis of non-causality at the $1 \%$ and $10 \%$ significance levels.

Source: Research results

The results show that a bidirectional causality exists between money and income, which is consistent with Badarudin et al. (2009) and Işık and Kahyaoglu (2010), confirming monetary endogeneity in Turkey. Furthermore, changes in broad money supply (M2) explain income fluctuations in Turkey, as stated by Hafer and Kutan (2002). The bidirectional causality may arise from non-linearities existing in the data, as argued by Holmes and Hutton (1992) and Sephton (1995), who propound that changes in money affect non-linearly income.

\section{CONCLUSION}

The purpose of this study is to contribute to the empirical investigation of the money-income nexus, emphasizing the fundamental role of causality testing. As the asymptotic critical values are not valid for causality tests if the variables are integrated and/or the assumption of normality is not fulfilled, we utilize an alternative methodology based on the leveraged bootstrapped simulation technique to calculate critical values. The results indicate that monetary aggregates still could help forecasting real income, at least to some extent in the Turkish economy, and money is not neutral in its effect-it is endogenous to a great extent. However, none of these results provides a compulsory reason to assign a prominent role to monetary aggregates in the practice of monetary policy. An inflation-targeting central bank, such as Central Bank of Turkey, should benefit from all of the sources of information available to it in implementing and judging the interest rate policy that should be consistent with its inflation target. Monetary aggregates may provide relevant information in judging the economy's state and hence the appropriate instrument setting, but this doesn't mean that monetary policy has to make a target for them. As a result, interest rate is an appropriate policy instrument in economies where monetary endogeneity exists. 


\section{REFERENCES}

Andersen, Leonall C. and Jerry L. Jordon, "Monetary and Fiscal Actions: A Test of Their Relative Importance in Economic Stabilization", Federal Reserve Bank of St. Louis Review November, (1969): 11-23.

Badarudin, Zatul E. , Ahmed M. Khalid, and Mohamed Ariff, "Money supply behaviour in emerging economies: a comparative analysis", Journal of the Asia Pacific Economy 14, no: 4, (2009): $331-350$

Barro, Robert J. , "Rational expectations and the role of monetary policy", Journal of Monetary Economics 2, no: 1, (1976): 1-32.

Bhargava, Alok, "On the theory of testing for unit roots in observed time series", Review of Economics Studies 53, no: 3, (1986): 369-384.

Christiano, Lawrence J. and Lars Ljungqvist, "Money does Granger-cause output in the bivariate money and output relation", Journal of Monetary Economics 22, no:2, (1988): 217235.

Demery, David, “Aggregate Demand, Rational Expectation and Real Output: Some Evidence for U. K. 1963.2-1982.2", Economic Journal 94, no: 376, (1984): 847-862.

Doornik, Jurgen A. and Henrik Hansen, "An Omnibus Test for Univariate and Multivariate Normality", Oxford Bulletin of Economics and Statistics 70, no: 1, (2008): 927-939

Eichenbaum, Martin and Kenneth I. Singleton, "Do equilibrium real business cycle models explain postwar US business cycles?", in NBER Macroeconomics Annual Vol.1, edited by Stanley Fischer, 91-146, MIT Press, 1997.

Elliot, Graham, Thomas J. Rothenberg, and James H. Stock, "Efficient tests for an autoregressive unit root", Econometrica 64, no: 4, (1996): 813-836.

Fisher, Stanley, "Long-term contracts, rational expectations and the optimal money supply rule", Journal of Political Economy 85, no: 1, (1997): 191-205.

Friedman, Milton. A Program for Monetary Stability, Fordham University Press, New York, 1959

Friedman, Milton and Anna Schwartz. A Monetary History of the United States, Princeton, Princeton University Press, 1963

Friedman, Benjamin M. and Kenneth K. Kuttner, "Another look at the evidence on moneyincome causality", Journal of Econometrics 57, no:1-3, (1993): 189-203.

Goodfriend, Marvin and Robert G. King, "The New Neoclassical Synthesis and the Role of Monetary Policy", in NBER Macroeconomics Annual Vol.12, edited by Ben Bernanke and Julio J. Rotemberg, 289-293, MIT Press, 1997

Gordon, Robert J. , "Price Inertia and Policy Ineffectiveness Debate in the United States, 18901980," Journal of Political Economy 90, no: 6, (1982): 1087-1117.

Gray, Jo A. , "Wage-indexation: a macroeconomic approach", Journal of Monetary Economics 2, no: 2, (1976): 221-236.

Hacker, R. Scott and Abdulnasser Hatemi-J. , "A multivariate test for ARCH effects", Applied Economics Letters 12, no: 7, (2005): 411-17.

Hacker, R. Scott and Abdulnasser Hatemi-J. , "Tests for causality between integrated variables using asymptotic and bootstrap distributions: Theory and application", Applied Economics 38, no: 13, (2006): 1489-1500.

Hacker, R. Scott and Abdulnasser Hatemi-J., "The Properties of Procedures Dealing with Uncertainty about Intercept and Deterministic Trend in Unit Root Testing", Working Paper Series in Economics and Institutions of Innovation 214, Royal Institute of Technology, CESIS - Centre of Excellence for Science and Innovation Studies, 2010

Hafer, Rick W. and Ali M. Kutan, "Detrending and the Money-Output Link: International Evidence", Southern Economic Journal 69, no: 1, (2002): 159-174. 
Hatemi-J, Abdulnasser, "A new method to choose optimal lag order in stable and unstable VAR models", Applied Economics Letters 10, no: 3, (2003): 135-137.

Hatemi-J, Abdulnasser and Manuchehr Irandoust, "Bootstrap-corrected causality test: another look at the money-income relationship", Empirical Economics 31, no: 1, (2006): 207-216

Hatemi-J, Abdulnasser, "Forecasting properties of a new method to choose optimal lag order in stable and unstable VAR models", Applied Economics Letters 15, no: 4, (2008): 239-243.

Holmes, James M. and Patricia A. Hutton, "A new test of money/income causality", Journal of Money, Credit, and Banking 24, no: 3, (1992): 338-355.

Isık, Sayım and Hakan Kahyaoglu, "The Endogenous Money Hypothesis: Some Evidence from Turkey (1987-2007)", Journal of Money, Investment and Banking 19, (2010): 61-71.

Kydland, Finn E. and Edward C. Prescott, "Time to build and aggregate fluctuations", Econometrica 50, no: 6, (1982): 1345-1370.

Long, John B. and Charles I. Plosser, "Real business cycles", Journal of Political Economy 91, no: 1, (1983): 39-69.

Lucas, Robert E. , "Expectations and the neutrality of money", Journal of Economic Theory 4, no: 2, (1972): 103-124.

Lucas, Robert E. , "An equilibrium model of the business cycle", Journal of Political Economy 83, no: 6, (1975): 1113-1144.

$\mathrm{Ng}$, Serena and Pierre Perron, "Lag Length Selection and the Construction of Unit Root Tests with Good Size and Power", Econometrica 69, no: 6, (2001): 1519-1554.

Palley, Thomas I. , "Competing Views of Money Supply Process: Theory and Evidence", Macroeconomics 45, no: 1, (1994): 67-88.

Phillips, Peter C. B. , "Time series regression with a unit root", Econometrica 55, no: 2, (1987): 311 340.

Phillips, Peter. C. B. and Pierre Perron, "Testing for a unit root in time series regression", Biometrica 75, no: 2, (1998): 335-346.

Sargent, Thomas J. and Neil Wallace, "Rational Expectations, the Optimal Monetary Instrument, and the Optimal Money Supply Rule", Journal of Political Economy 83, no: 2, (1975): 241-254.

Serletis, Apostolos and Martin King, "Deterministic Trends and Money-Output Causality", Applied Financial Economics 4, no: 2, (1994): 143-47.

Sims, Christopher A. , "Money, income, and causality", American Economic Review 62, no: 4, (1972): 540-552.

Sims, Christopher A. , "Comparison of interwar and postwar business cycles: monetarism reconsidered", American Economic Review 70, no: 2, (1980): 250-257.

Sephton, Peter S. "A non-parametric view of money/income causality", Applied Financial Economics 5, no:2, (1995): 79-84.

Stock, James H. and Mark W. Watson, "Interpreting the evidence on money-income causality", Journal of Econometrics 40, no: 1, (1989): 161-81.

Taylor, John B. , "Aggregate dynamics and staggered contracts", Journal of Political Economy 88, no: 1, (1980): 1-23.

Toda, Hiro Y. and Taku Yamamoto, "Statistical Inference in Vector Autoregressions with Possibly Integrated Processes", Journal of Econometrics 66, no: 1-2, (1995): 225-50. 


\section{NOVAC, PRIHOD I KAUZALNOST: ISPITIVANJE TURSKE EKONOMIJE}

Sažetak: Ovaj rad istražuje smjer kauzalnosti između novca i dohotka u turskoj ekonomiji koristeći kvartalne podatke za period od 1987. do 2011. Vektorski autoregresijski model koji sadržava realni bruto domaći proizvod, opskrbu novcem u širem smislu, tromjesečnu stopu depozita kao kratkoročnu kamatu i potrošački cjenovni indeks sastavljen je u svrhu provođenja testova kauzalnosti. Osim toga, „leveraged bootstrap“ simulacijska tehnika je korištena pri provođenju testova kauzalnosti kako bi rezultati bili robustniji. Empirijski rezultati sugeriraju postojanje dvosmjerne kauzalnosti između dvije varijable te da novčani agregati mogu pružiti relevantne informacije za implementaciju monetarne politike.

Ključne riječi: kauzalnost novca i prihoda, monetarna endogenost, MWALD test, leveraged bootstrap" simulacija, Toda-Yamamoto 
Şeref Bozoklu

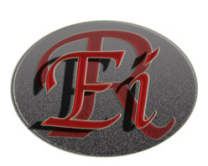

